\title{
MECHANICAL PROPERTIES OF HEMP (CANNABIS SATIVA) BIOMASS
}

\author{
Andris Kronbergs, Elgars Širaks, Aleksandrs Adamovičs, \\ Ëriks Kronbergs \\ Latvia University of Agriculture \\ Liela Street 2, Jelgava, LV 3001, Latvia; e-mail: andrisk@1lu.lv
}

\begin{abstract}
In Latvia approximately of $14.6 \%$ of unfarmed agricultural land can be used for herbaceous energy crop growing. Herbaceous energy crops would be as the main basis for solid biofuel production in agricultural ecosystem in future. Herbaceous energy crops as hemp (Cannabis sativa) are grown in recent years and can be used for solid biofuel production. Experimentally stated hemp stalk material ultimate tensile strength the medium value is $85 \pm 9 \mathrm{~N} \mathrm{~mm}^{-2}$. The main conditioning operation before preparation of herbaceous biomass compositions for solid biofuel production is shredding. Therefore hemp stalks were used for cutting experiments. Cutting using different types of knives mechanisms had been investigated. Specific shear cutting energy for hemp samples were within $0.02-0.04 \mathrm{~J} \mathrm{~mm}^{-2}$. Hemp stalk material density was determined using AutoCAD software for cross-section area calculation. Density values are $325 \pm 18 \mathrm{~kg} \mathrm{~m}^{-3}$ for hemp stalks. Specific cutting energy per mass unit was calculated on basis of experimentally estimated values of cutting energy and density.
\end{abstract}

Keywords: energy crops, hemp, mechanical properties.

\section{Introduction}

Latvia has target [1] in 2020 for renewable energy resources to be $40 \%$ in gross final consumption of energy. In 2005 EU biomass accounted for $66 \%$ [2] of renewable primary energy production. Biomass has relatively low costs, less dependence on short-term weather changes and it is possible alternative source of income for farmers. Herbaceous energy crops would be as the main basis for biofuel production in agricultural ecosystem in future. There is not problem in Latvia that if bioenergy crops are encouraged, then less land will be available for growing food. In 2005 year investigation was stated that $14.6 \%$ of agricultural land [2] of Latvia was unfarmed. Therefore herbaceous energy crop growing on these lands can provide sustainable farming practice. Sources of renewable energy are also by-products of hemp (Cannabis sativa) straw of the process of fiber extraction and the whole plants of hemp cultivated for biomass. Hemp and waste hemp residues after processing can be used for production of solid biofuel pellets and briquettes.

The main conditioning operation before compacting of herbaceous biomass in shape of pellets and briquettes is shredding. It is size reduction of biomass stalks and residues by cutting operation. In Latvia hemp growing as biomass for solid fuel production is new activity. For this reason mechanical properties of different varieties of hemp have to be investigated in order to develop shredding equipment design methodology. Mainly shear strength of hemp samples were investigated in order to find methods for cutting (shredding) with minimal energy consumption. The main hypothesis for cutter design is that cutting method has to be used with minimum of energy consumption by reducing frictional forces to a minimum. Different cutting knives mechanisms have to be investigated for energy consumption evaluation. The objective of this study is to determine cutting properties of hemp stalk materials and energy efficiency of cutting knives mechanisms.

\section{Materials and methods}

Herbaceous biomass as hemp is prospective stalk materials for solid biofuel production in Latvia. For production of solid biofuel mainly herbaceous plant stalks are used. Hemp 
(Cannabis sativa) in Latvia is cultivated only in recent years and it mechanical properties are not broadly investigated. Cross-sections of hemp stalks show the complicated structure (Figure 1) of this material. It can be noticed that hemp stalks have significant woody part resource for solid biofuel production.

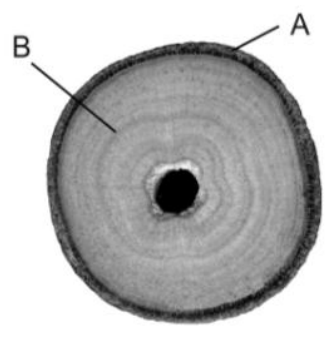

Fig.1. Hemp stalk cross-section

(A - fibrous layer, B - woody part)

As sample materials for investigation of cutting properties eight varieties of hemp were used in experiments. Average biomass yield in DM (in 2010) of hemp varieties are presented in Table 1.

Table 1.

Hemp biomass in DM yields

\begin{tabular}{|c|c|}
\hline Hemp variety & ${\text { Yield, } \mathrm{t} \mathrm{ha}^{-1}}^{-1}$ \\
\hline Bialobrzeskie & 14,0 \\
\hline Felina 32 & 13,2 \\
\hline Epsilon 68 & 15,8 \\
\hline Benico & 12,7 \\
\hline Uso - 31 & 14,4 \\
\hline Futura 75 & 16,9 \\
\hline Fedora 17 & 15,9 \\
\hline Santhica 27 & 16,4 \\
\hline
\end{tabular}

Hemps, with moisture content $\sim 10 \%$, were used for density calculation and experiments for investigation of mechanical properties.

Mostly hemp stalk material cross-section shape is irregular; therefore cross-section area can't be calculated by using geometry equations. For irregular cross-section area calculation AutoCAD software functions "Spline", "Region"and "Object properties" (Figure 2) had been used. The scanned hemp stalk sross-section images in real measurements for area calculation were used. Bouth border lines of cross section were marked with function "Spline". With function "Region" the area included in border lines is marmed. For bouth regions in "Object properties" areas in $\mathrm{mm}^{2}$ are shown. The difference between outside border region area and inside border region area is a real hemp stalk cross-secrion area. By using function "Substract" is possible to cut out inner region from outer region. In that way in "Object properties" is shown real hemp stalk cross-section area.

Cross-section area was calculated from data obtained from direct measurement with sliding caliper (accuracy $\pm 0,01 \mathrm{~mm}$ ). Hemp stalk cross-section area was used in material density and mechanical properties calculations. In density calculations for each stalk test piece were determined cross-section areas for both stalk ends. By multiplication of average area and length the volume of each test piece was found. Volume values were used for density calculation. 


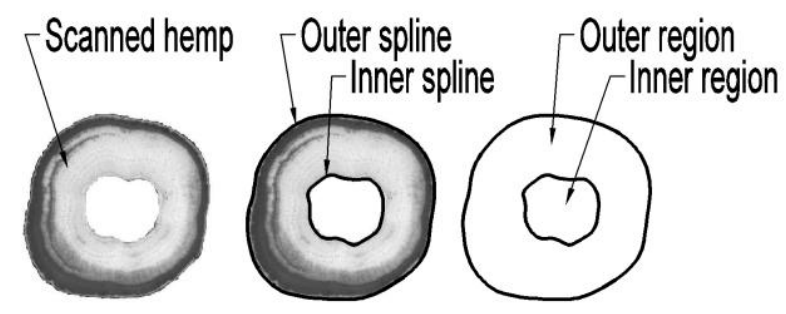

Fig.2. Cross-section area calculation in AutoCAD software

Ultimate shear strength and energy consumption for stalk cutting has been investigated using the Zwick materials testing machine TC-FR2.5TN.D09 with force resolution 0,4\% and displacement resolution $0,1 \mu \mathrm{m}$ and the maximal force for testing $2,5 \mathrm{kN}$. For shear cutting parameter determination original cutting device has been designed. For all experiments the displacement speed of cutting knives did not exceeds $50 \mathrm{~mm} \mathrm{~min}^{-1}$. Cutting device was equipped with five different cutting knives mechanisms (Figure 3).

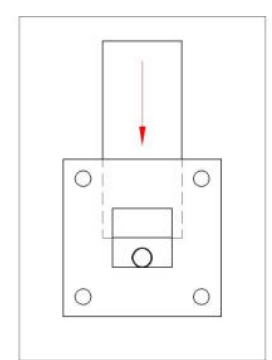

№ 1

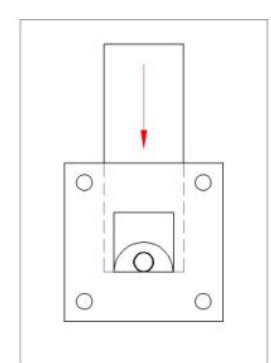

№ 2

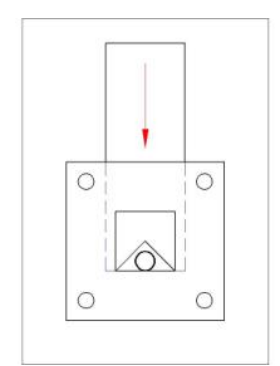

№ 3

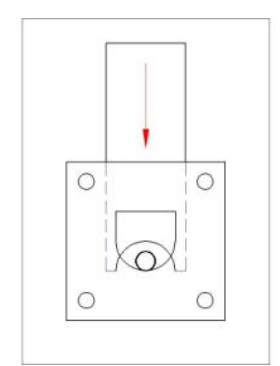

№ 4

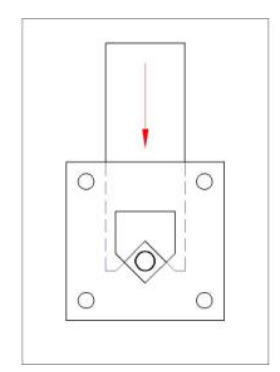

№ 5

Fig.3. Shear cutting knives mechanisms

Ultimate shear strength was calculated:

$$
\tau_{C}=\frac{F_{C}}{A}
$$

where: $\quad \tau_{C}$ - ultimate shear strength, $\mathrm{N} \mathrm{mm}^{-2}$;

$F_{C}$ - maximal cutting force, $\mathrm{N}$;

$A$ - cutting area, $\mathrm{mm}^{-2}$.

Specific cutting energy was determined:

$$
E_{S C}=\frac{E_{C}}{A}
$$

where: $\quad E_{S C}$ - specific cutting energy, $\mathrm{J} \mathrm{mm}^{-2}$;

$E_{C}$ - cutting energy, $\mathrm{J}$;

$A$ - cutting area, $\mathrm{mm}^{-2}$.

Displacement and stress data were collected and processed by using Zwick software program TestXpert V9.01. The energy consumption was obtained by integrating force - displacement diagram. Specific cutting energy consumption was investigated for all varieties of hemp. For investigation of each knives mechanism were used 15 samples of every plant stalk material variety.

Results of cutting experiments were processed by Microsoft Excel program. 
The cutting (chopping) energy $E$ for stalk material mass unit is calculated [3] using equation:

$$
E=\frac{E_{S C}}{L_{C} \cdot \rho}
$$

where: $\quad E$ - cutting energy per mass unit, $\mathrm{J} \mathrm{kg}^{-1}$;

$L_{C}$ - length of stalk cut, mm;

$\rho$ - stalk material density, $\mathrm{kg} \mathrm{mm}^{-3}$.

Ultimate tensile strength for hemp stalk has been investigated using the GUNT 20 materials testing machine with force resolution $1 \%$ and displacement resolution $10 \mu \mathrm{m}$ and the maximal force for testing is $20 \mathrm{kN}$. For average ultimate tensile strength determination original clamping part has been designed (Fig. 4).

Ultimate tensile strength was calculated:

$$
\sigma=\frac{F_{P}}{A}
$$

where: $\quad \sigma$ - ultimate tensile strength, $\mathrm{N} \mathrm{mm}^{-2}$;

$F_{P}$ - maximal tensile force, $\mathrm{N}$;

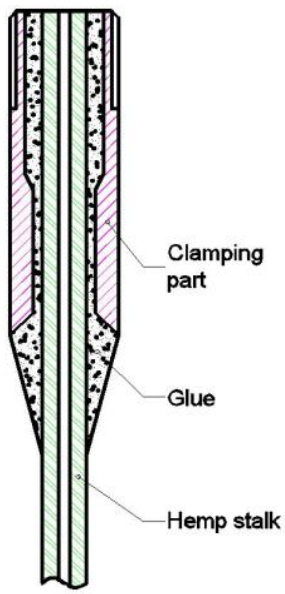

$A$ - stalk cross-section area, $\mathrm{mm}^{-2}$.

Fig.4. Hemp stalk gripper mechanism

\section{Results and discussion}

Hemp stalk material ultimate shear cutting strength and specific cutting energy is shown in Table 2. Average specific cutting energy for hemp stalks is within $0.02-0.04 \mathrm{~J} \mathrm{~mm}^{-2}$.Hemp stalk material ultimate shear cutting strength and specific cutting energy is shown in Table 2. Average specific cutting energy for hemp stalks is within $0.02-0.04 \mathrm{~J} \mathrm{~mm}^{-2}$.

Table 2.

\begin{tabular}{|c|c|c|c|c|c|c|c|c|c|c|}
\hline & \multicolumn{10}{|c|}{ Cutting mechanism } \\
\hline & \multicolumn{2}{|c|}{ № 1} & \multicolumn{2}{|c|}{ № 2} & \multicolumn{2}{|c|}{ № 3} & \multicolumn{2}{|c|}{ № 4} & \multicolumn{2}{|c|}{ № 5} \\
\hline Sample & $\begin{array}{c}\tau_{\max } \\
\mathrm{N} \\
\mathrm{mm}^{-2}\end{array}$ & $\begin{array}{c}\mathrm{E}, \\
\mathrm{J} \\
\mathrm{mm}^{-2}\end{array}$ & $\begin{array}{c}\tau_{\max }, \\
\mathrm{N} \\
\mathrm{mm}^{-2}\end{array}$ & $\begin{array}{c}\mathrm{E}, \\
\mathrm{J} \\
\mathrm{mm}^{-2}\end{array}$ & $\begin{array}{c}\tau_{\max }, \\
\mathrm{N} \\
\mathrm{mm}^{-2}\end{array}$ & $\begin{array}{c}\mathrm{E}, \\
\mathrm{J} \\
\mathrm{mm}^{-2}\end{array}$ & $\begin{array}{c}\tau_{\max }, \\
\mathrm{N} \\
\mathrm{mm}^{-2}\end{array}$ & $\begin{array}{c}\mathrm{E}, \\
\mathrm{J} \\
\mathrm{mm}^{-2}\end{array}$ & $\begin{array}{c}\tau_{\max }, \\
\mathrm{N} \\
\mathrm{mm}^{-2}\end{array}$ & $\begin{array}{c}\mathrm{E}, \\
\mathbf{J} \\
\mathrm{mm}^{-2}\end{array}$ \\
\hline Bialobrzeskie & 14.9 & 0.021 & 15.3 & 0.023 & 11.8 & 0.030 & 14.1 & 0.024 & 15.5 & 0.037 \\
\hline Felina 32 & 15.8 & 0.025 & 17.0 & 0.026 & 14.4 & 0.035 & 15.6 & 0.031 & 13.5 & 0.037 \\
\hline Epsilon 68 & 13.8 & 0.020 & 15.9 & 0.022 & 13.8 & 0.028 & 14.6 & 0.023 & 14.4 & 0.029 \\
\hline Benico & 18.9 & 0.031 & 19.4 & 0.029 & 18.8 & 0.045 & 18.9 & 0.032 & 19.0 & 0.043 \\
\hline Uso - 31 & 16.6 & 0.030 & 17.1 & 0.032 & 13.4 & 0.039 & 17.8 & 0.039 & 13.3 & 0.047 \\
\hline Futura 75 & 17.5 & 0.030 & 18.4 & 0.030 & 15.9 & 0.041 & 17.3 & 0.034 & 16.1 & 0.042 \\
\hline Fedora 17 & 13.5 & 0.022 & 14.3 & 0.021 & 12.3 & 0.029 & 12.6 & 0.022 & 13.1 & 0.028 \\
\hline Santhica 27 & 17.0 & 0.030 & 17.7 & 0.029 & 15.4 & 0.037 & 16.4 & 0.029 & 16.4 & 0.038 \\
\hline $\begin{array}{l}\text { Average for } \\
\text { hemp }\end{array}$ & 16.0 & 0.026 & 16.9 & 0.026 & 14.5 & 0.036 & 15.9 & 0.029 & 15.2 & 0.038 \\
\hline
\end{tabular}

Hemp and common reed stalk material mechanical properties

The cutting knives mechanisms № 1 and № 2 are approved as the most energy efficient, where the average cutting energy consumption for hemp stalks is minimal $\left(0.026 \pm 0.003 \mathrm{~J} \mathrm{~mm}^{-2}\right)$. Cutting knives mechanism with round shape (№ 2) is recommended 
because the rounding in cutting knives are increasing nip angle. Increased nip angle improve the biomass shredder technical parameters by reducing rotation speed deviation and wear of cutting and counter knives.

The cutting mechanism № 3 is recommended then it is necessary to reduce cutting force values, because minimal average ultimate shear strength is $14.5 \pm 1.9 \mathrm{~N} \mathrm{~mm}^{-2}$. For all cutting knives mechanisms cutting parameters depend on material deformation process during cutting. The ultimate shear strength values are decreasing if bevel angle for knives is increased. But increased bevel angle causes significant material deformation, therefore specific cutting energy is increasing.

Specific cutting energy of hemp stalks with mechanism № 2 is shown in Figure 4. It can be noted that specific cutting energy is increasing if hemp sample cross-section is increased.

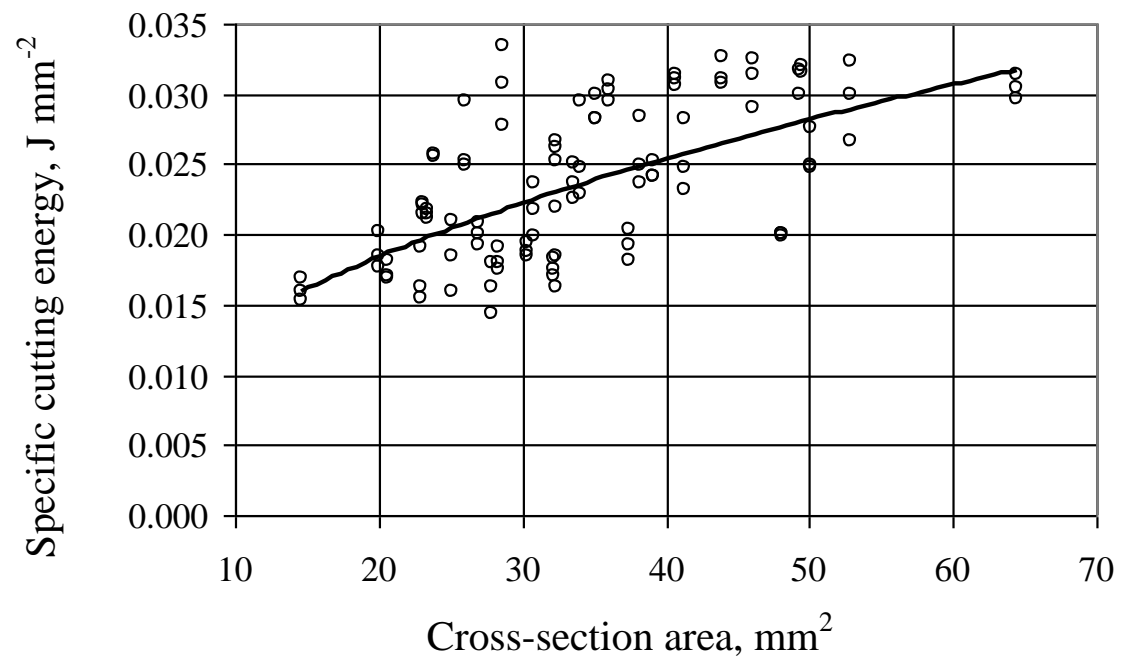

Fig.4. Specific cutting energy of cutting mechanism № 2

Ultimate tensile strength of different hemp varieties samples depending on cross-section area is shown in Figure 5. The average hemp stalk material ultimate tensile strength is calculated $85 \pm 9 \mathrm{~N} \mathrm{~mm}^{-2}$.

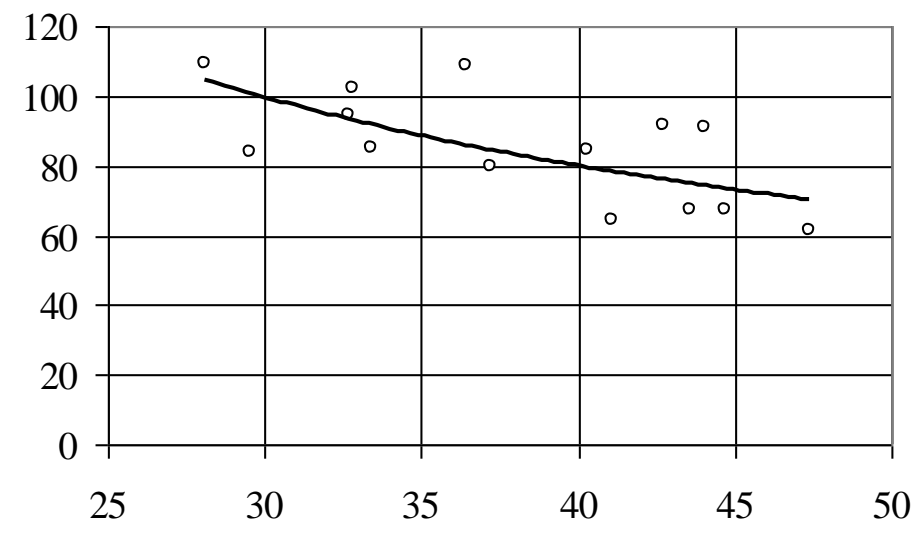

Cross-section area, $\mathrm{mm}^{2}$

Fig.5. Hemp stalks material ultimate tensile strength 
The trendline shows that hemp test piece area increasing causes decreasing of ultimate tensile strength. Figures 4 and Figure 5 shows that there is significant dependence between stalk mechanical properties and ratio of cross-section area and perimeter. For all hemp samples there are tendency of specific cutting energy growing and ultimate tensile strength decreasing, if cross-section area is increasing.

Investigated hemp stalk material density is shown in Table 3.

Table 3.

Hemp biomass density

\begin{tabular}{|c|c|}
\hline Hemp variety & Density, $\mathrm{kg} \mathrm{m}^{-3}$ \\
\hline Bialobrzeskie & 300 \\
\hline Felina 32 & 340 \\
\hline Epsilon 68 & 310 \\
\hline Benico & 340 \\
\hline Uso - 31 & 320 \\
\hline Futura 75 & 340 \\
\hline Fedora 17 & 300 \\
\hline Santhica 27 & 360 \\
\hline
\end{tabular}

The average calculated hemp stalk material density is $325 \pm 18 \mathrm{~kg} \mathrm{~m}^{-3}$. These values are used in cutting knives mechanism cutting energy per mass unit calculation (Figure 6). It can be noticed that for hemp varieties Fedora 17 and Bialobrzeskie have the least values of density $\left(300 \mathrm{~kg} \mathrm{~m}^{-3}\right)$ and also the least value of specific cutting energy $\left(0.021\right.$ and $\left.0.023 \mathrm{~J} \mathrm{~mm}^{-2}\right)$ with cutting knives mechanism № 2. It can be concluded that the minimum values of specific cutting energy are for hemp samples with least values of density.

On basis of calculated stalk material density specific cutting energy per mass unit (Figure 6) is determined. Specific cutting energy per mass unit is growing considerably when shredding size is less than $30 \mathrm{~mm}$ for hemp stalk material.

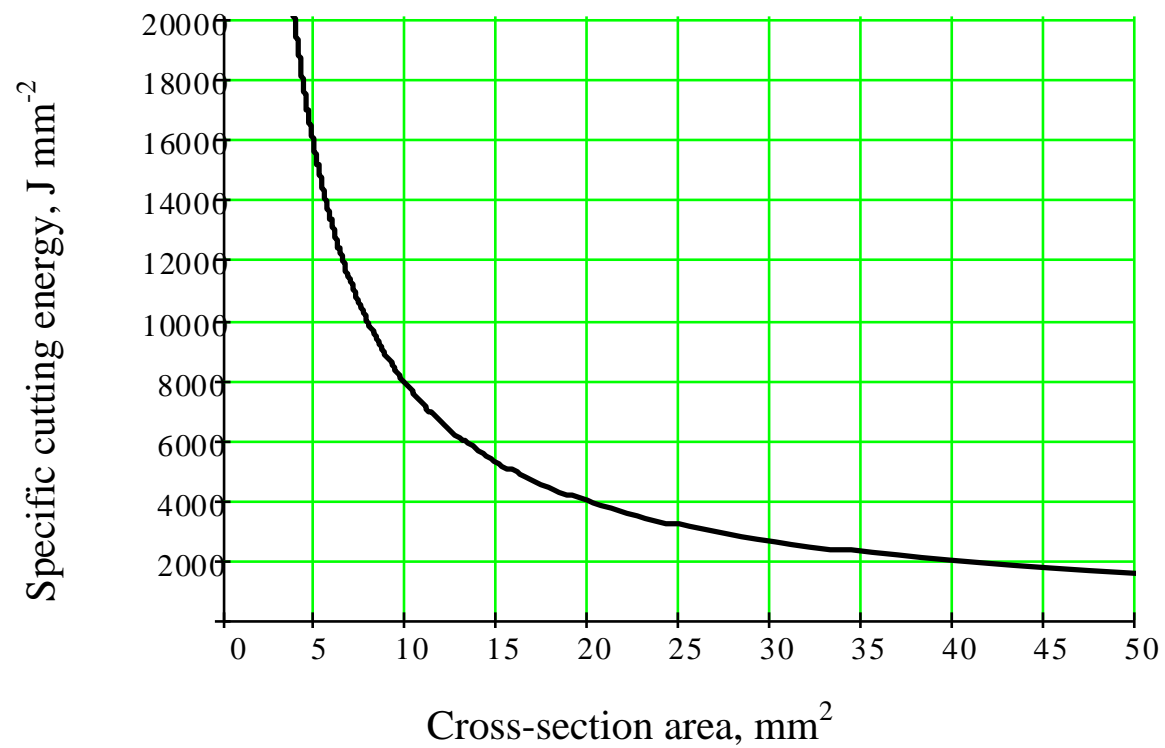

Fig.6. Hemp stalk material cutting energy 


\section{Conclusion}

Average specific shear cutting energy is within $0.02-0.04 \mathrm{~J} \mathrm{~mm}^{-2}$ for hemp stalks. The cutting knives mechanism № 2 is approved as the most energy efficient, where the average cutting energy consumption for hemp stalks is $0.026 \pm 0.003 \mathrm{~J} \mathrm{~mm}^{-2}$.

The cutting mechanism № 3 is recommended then it is necessary to reduce cutting force values, because minimal average ultimate shear strength is $14.5 \pm 1.9 \mathrm{~N} \mathrm{~mm}^{-2}$ for hemp samples.

The average hemp stalk material ultimate tensile strength is $85 \pm 9 \mathrm{~N} \mathrm{~mm}^{-2}$.

For all hemp samples there are tendency of specific cutting energy growing and ultimate tensile strength decreasing, if cross-section area is increasing.

The average calculated hemp stalk material density is $325 \pm 18 \mathrm{~kg} \mathrm{~m}^{-3}$.

Hemp varieties Fedora 17 and Bialobrzeskie have the least values of density $\left(300 \mathrm{~kg} \mathrm{~m}^{-3}\right)$ and also the least value of specific cutting energy $\left(0.021\right.$ and $\left.0.023 \mathrm{~J} \mathrm{~mm}^{-2}\right)$ with cutting knives mechanism № 2 .

\section{Acknowledgment}

The authors are grateful for the financial support of this research from the European Structural Fund - Mobilization of human resources to renewable energy research - Project of Latvia University of Agriculture (project No 2009/0225/1DP/1.1.1.2.0/09/APIA/VIAA/129).

\section{References}

1. Directive 2009/28/EC of the European Parliament and of the Council of 23 April 2009 on the promotion of the use of energy from renewable sources and amending and subsequently repealing Directives 2001/77/EC and 2003/30/EC (Text with EEA relevance).

http://eur-lex.europa.eu/LexUriServ/LexUriServ.do?uri=CELEX:32009L0028:EN:NOT, (Accessed on 30.03.2010).

2. Land politics statement for years 2008. - 2014. The Order of the Cabinet of Ministers of the Republic of Latvia Nr. 613 (in Latvian), http://www.mk.gov.lv, (Accessed on 30.03.2010).

3. Srivastava AK, Goering CE, Rohrbach RP. Engineering principles of agricultural machines. ASAE Textbook Number 6. Pamela De Vore-Hansen, Editor, Books\&Journals. 1993. p. 601.

Anotācija. Latvijā aptuveni $14.6 \%$ no lauksaimniecībā neizmantojamās platības var tikt izmantota energètisko stiebraugu audzēšanai. Energétisko stiebraugu audzēšana lauksaimniecībā nākotnē varētu būt kā galvenais cietā kurināmā ražošanai nepieciešamais izejvielu avots. Sējas kaņepju (Cannabis sativa) audzēšana Latvijā notiek tikai pēdējos gados un varētu tikt izmantota kā izejviela cietā kurināmā ražošanai. Eksperimentāli

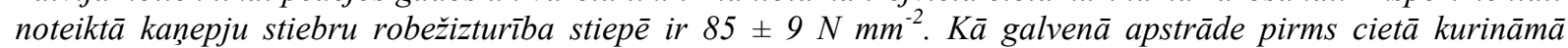
ražošanas ir smalcināšana, tādēl kaņepju stiebri tika izmantoti griešanas pētījumos. Griešanas pētījumos tika izpètīti pieci dažādi griešanas mehānismi. İpatnējā griešanas energija kañepju stiebraugiem bija robežās no $0.02-0.04 \mathrm{~J} \mathrm{~mm}^{-2}$. Kaņepju stiebraugu materiāla blīvums tika noteikts, izmantojot datorprogrammā AutoCAD aprēķinātos stiebra šķērsgriezuma laukumus. Kaņepju stiebru materiāla blīvums ir $325 \pm 18 \mathrm{~kg} \mathrm{~m}^{-3}$. Stiebru materiāla griešanas energija uz masas vien̄̄bu ir aprēķināta, izmantojot eksperimentāli iegūtās materiāla blīvuma un ìpatnējās griešanas energijas vērtības. 